\title{
Varieties of Communist System Transformation and Their Common Systemic Grounds: A Comparative Study of China and East European Countries
}

\author{
Maria Csanádi \\ csanadi.maria@mta.krtk.hu \\ Institute of Economics \\ Center for Economic and Regional Studies \\ Budapest, Budaörsi út 45 \\ Hungary 1112 \\ Phone (+36 30) 8164260 \\ Fax:+ (+36-1) 309-2650
}

Funding: This work was supported for decades by the Institute of Financial Research, the

Social Science Institute and the Institute of Economics in Hungary, and the Beijing Normal University SEBA in China. From 2002 on, the research project was financed by the

Hungarian National Research Fund. 


\begin{abstract}
This paper analyzes the similarities and differences in the structure and dynamics of partystatesystems and their different metamorphosis from a comparative perspective. This approach allows interpretation of the Chinese system specifics and its transformation within this framework. Theoretical findings are based on empirical reseach carried out in Hungary, Romania and China by the author between 1975 and 2014. Empirical research revealed a politically monopolized interactive and intertwined network of dependency and interest promotion among actors in the party, the state and the economy during decision-making. This network possesses similar elements and connecting and operating principles whatever the time, the space and the level of its aggregation. It renders the structural background of power distribution and that of the politically rational behavior of economic actors in the selective distribution of resources and in the overall drive for growth resulting in frequent investment overheating and overcapacity. The comparative framework also defines the structural varieties of power distribution in the network that are responsible for the differences in the operation and the sequence, speed, and conditions of system transformation.
\end{abstract}

Keywords: party-state systems, network, varieties of power distribution, transformation, China, Hungary

JEL: P2, P5, D78, F5, P21, P26, P30

\title{
1. Introducion
}




\subsection{Diverging approaches to East European and Chinese transformations}

The transformation process may be defined as the retreat of the power network from politically monopolized sub-spheres of society (be they political or economic) and the emergence and expansion of the subfield of a new system outside the network. With social system transformation structural elements, the connecting and operating principles characteristic of Communist systems wane while the characteristics of a new system emerge. The various transformations of Communist systems which began at different periods, and in different fields of society, have concluded or are still in process. This process occurred in the Soviet Union and East-Europe from the second half of the 1980s to early 1990s, in China it began in agriculture from 1978 onwards, it partially spread to industry in the mid 1980s and intensified from the early 1990s. Different sub-fields of the system transformed either sequentially or simultaneously. Either the political or the economic sub-field was the first to transform, or all subfields transformed simultaneously. These transformations were gradual or abrupt and occurred under different economic and political conditions, and systemic outcomes were multiple. Party-states with different sequences of transformation were also regionally and culturally dispersed: first political transformation occurred in Europe while first economic transformation occurred in China.

Sequential difference, field of interest and regional dispersion attracted different groups of scholars with different focuses dealing with the transformation of party-states: scholars interested in political reforms concentrated on European states and Russia, and those interested in economic reforms focused primarily on China. Owing to their different interests, their field of comparison remained spatially segregated and the sequential variety of transformation was neglected. In content they also rarely "overlapped", and when they did analysts used comparisons mostly as negative examples: China experts criticized the deep economic crisis in those states where political transformation occurred first, while 
"transitologists" distanced themselves due to the persistent authoritarianism in China where economic transformation took place first.

Consequently, in Eastern Europe and the Soviet Union "transition to democracy" and "transformational recession" became a hot topic for more than a decade in comparative literature (Aslund, 1993; Gelb, et al. 1994; Gomulka, 1994; Sachs, 1994; Sachs and Woo, 1997; Hellman, 1998; World Bank, 1996; Kornai, 1994). The perspective of China experts' differed from that of "transitologists". The overall success of the radical economic reforms of the early 1980s in agriculture was followed by the more constrained institutional and economic reforms in industry in the mid 1980s which were halted by conservative forces. Economic transformation resulting in successful growth intensified from the early 1990s onwards. This latter development followed a strong economic recession due to overall economic restrictions and a political clamp down by the Chinese political regime intended to escape from internal economic and political pressures and the domino effect of regime collapse.

Based on these facts, China experts focused on economic reforms. From the early 1990s onwards the debate between transitologists and Chinologists heated up. Contentious issues were the "ideal sequence", speed, location and political context of economic reforms. Chinologists argued that reforms should not start with political change but with economic reform designed to induce macroeconomic growth rather than economic crisis, engaging in gradual reforms rather than the shock therapy prioritized in Poland and Russia. They argued that reforms from "below" both in agriculture and in industry led to macroeconomic growth in China, rather than decentralizing reforms from "above" that ended in the loss of legitimacy of the Communist party and system transformation in Hungary by the end of the 1980s (Chen at al., 1992; Shirk, 1993; Solinger, 1993; Qian and Xu, 1993; Walder, 1995; Weingast, 1995; 
Naughton, 1996; Nolan, 1996; Pearson, 1997; Qian and Roland, 1998; Woo, 1998; Cao at al., 1999; Denglian and Haines, 1997).

After a decade, the scientific interest in transition in Europe faded away (Carothers, 2002). Comparative focus next shifted to the varieties of capitalism including post-communist states (Peck and Sun, 2013). Later, as the global crisis swept over the world's economies, attention in economics and comparative political science shifted to the dramatic consequences of the global crisis in Europe and Asia. However, the finally coinciding topic of research in both areas evolved at a time when comparison had already lost common systemic ground, as new system characteristics of post-communist states and those of the transforming communist system in China were not comparable.

\section{Bringing Chinese and European transformations to common grounds}

\subsection{The systemic approach}

This paper tries to retrieve missed opportunities by introducing a comparative political economic analytical framework based on empirical research. This is a bottom-up model that puts the different operations and transformations of party-state systems on common systemic ground no matter the time, the space or the level of aggregation or the issue to be compared. It also reveals the structural background of the differences of these systems in time, in space and aggregation levels and points to their dynamic consequences. Both similarities and differences in the structure and dynamics of party-state systems are embodied by the interactive power network formed by the dependency and interest promotion relationships of actors in the party, the state and the economy during the decision-making process. The logic of the evolution of this network towards the political monopolization of all sub-fields of the society will be described by the Interactive Party-State (IPS) model in the following sections. The IPS model involves the system's main elements, the connecting and operating principles, reveals the 
structural background of its self-similarities and disparities in space, in time and in different levels of aggregation as well as their consequences in operation and transformation (see in detail in Csanádi 1997; 2006; 2011)The network and its interactivity is crucial from the point of view of the dynamics of the system's self-reproduction, varieties of power distribution and transformation in Communist systems. As to the present, similar approaches that use network from the point of view of political economy to describe the complexity of a social system as a power relation, more specifically, as power relations in communist systems are rarely available. For example, Shumpei Kumon (1992) defines the network from the point of view of social science, where subtle and delicate economic, political and cultural individual actions and motivations produce social networks which diverge rather than interact in a power network. He adapts his theory to post-war Japanese society. Also Misruchi (2007) underlines the mutual importance of the combination of network theory and political economy. However, he discusses these networks in the partial fields of the capitalist system: corporate power, the corporate elite, international interlocks, interlocking directorate among corporations, corporate political action during a campaign to pass a bill etc. Partial networks among political and economic actors were also revealed on the interrelation of political and business elites: business networks of partisan firms (Stark and Vedres, 2012) or corporate interlocks and power structures (Huang, 1990; Pretorius, 2014). These works however, do not describe the intertwined and interactive nature of the network among party, state and economic decision-makers, reflecting power distribution in communist systems. Neither do they focus on the specific patterns of power distribution in the networks leading to pattern-conforming transformations. For example, none of these factors gain emphasis in Kornai's causal model on the operation of communist systems (Kornai, 1992, pp. 565-580) or in his thorough analysis on system paradigms (Kornai, 2000) despite acknowledging mutual influences in several directions. Without interactivity provided by the network the reasons for changes are unclear: what 
motivates the departure from the classical type of Communist system, ${ }^{1}$ why crisis takes place in this model and why reforms emerge? Why and how do decentralization, disintegration, collapse and transformation of party-states result from these causal dynamics without internal and external interactivity? What is the cause of the differences in operation and in the instruments of self-reproduction and transformation in Communist systems?

\subsection{The methodology of common grounds: networks in the structure and dynamics of party-state systems}

The IPS model demonstrates that party-state structures are neither strictly hierarchical, nor monolithic and reveals the institutional background of blurred boundaries between society and state, politics and economics, ruling elite and working classes, paternalistic state and economic units through several interlinked and interacting layers.

\footnotetext{
${ }^{1}$ This is a category used both by Kornai and other researchers when analyzing communist systems. They refer to the initial setting that was formed in all communist systems emulated from the Soviet model of the 1930s, no matter which period and which country. The so-called classical model prevailed in some countries until the collapse of the system (e.g. in Romania) or still prevails in others (as in North Korea). Despite their multiple variety according to local specifics (geopolitical context, cultural traditions, level of economic development, economic structure, size etc), their common feature was a centralized institutional and power structure. This power structure tended towards a totalitarian regime, with compulsory central planning involving units from central levels to the very bottom, with centralized resource extraction and distribution and frequent reorganizations of the power structure without reforms.
} 
In order to reveal the hidden characteristics of the decision-making structure, institutions, interdependencies, interest promotion and motivations that provide the dynamics of an opaque social system several case-studies were carried out by the author in Hungary during 19751989 on the decision-making process. First, the author conducted interviews, collected and analyzed documents and circulars, surveyed archives and used data from several dimensions of the decision-making process. The networks and their dynamic properties have been revealed by the author in the Hungarian party-state system as early as the 1980's binding together actors in the party, in the state and the economy. Later, elements, connecting and operating principles and the selective distribution of resources in this network were traced down (Csanádi, 1997). Further empirical studies and secondary analysis of other empirical works revealed the common features of this network: namely that the network looked similar at different levels of aggregation, e.g., at the level of enterprises, at the level of districts, countries, or even at the level of the Eastern Block, but also in time (at different periods) and in space (among different units of a given aggregation level) (Csanádi, 2006). Next, different aspects of party-state systems were interpreted from the point of view of the general and specific features of the network, thereby extending the model to party-states in general while in particular tracing down the metamorphosis of individual parties into systems and reversed in Hungary, Romania, and China (Csanádi, 2006). Later, in order to test the theoretical findings regarding extended general and specific features of the structure, operation and transformation new empirical surveys were carried out in China beteween 2001 and 2013. The remaining paper is divided into the following sections: the third section deals with the structure of party-states and the complex network, the fourth with the operation of partystates, the fifth summarizes the common structural and dynamic grounds to compare partystates; the sixth introduces the reasons and consequences of structural specifics of different 
party-states and the conditions of shifting structural specifics. Lastly, the seventh explores pattern-conforming transformations and their elements and is followed by the conclusion.

\section{The network structure of party-state systems}

The complex nework structure of party-state systems represented by the IPS model can be described in terms of hierarchical structures and the links between them. It is composed of three interactive layers that incorporate each other: the party and state hierarchies, the instruments of power of the party interlinking those hierarchies and the privileges of short-cuts for some in the decision-making process.

\subsection{The first layer}

The first layer is the basic network structure (Figure 1): it is formed by the set of formal hierachies that are already specific to party-states: the party hierarchy monopolizes the political subsphere, the state (non-party) hierarchy monopolizes the economic sub-sphere (and generally all other sub-spheres) and thereby both the extraction and distribution of resources and the instruments serving those. Still, in the this basic network structure, characteristics of hierarchies are clear: actors on one level are equally powerful towards lower levels and equally depend on higher levels of the hierarchy, dependency is unilinear, ie. there are no ways to circumvent direct subordination levels for interest promotion.

Figure 1 The first layer: the formal hierarchies of the party-state structure and varieties of interest promotion 


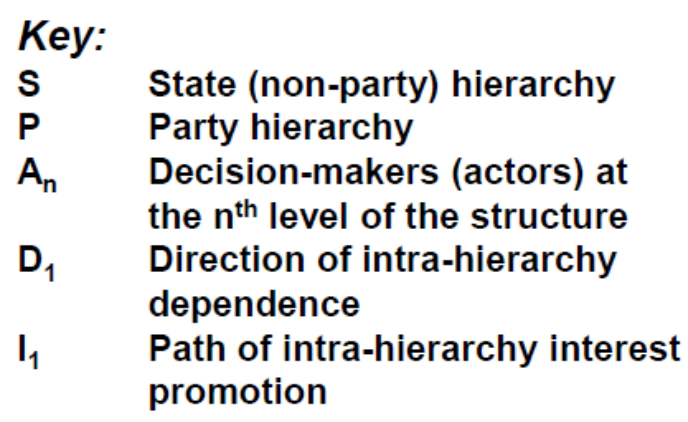

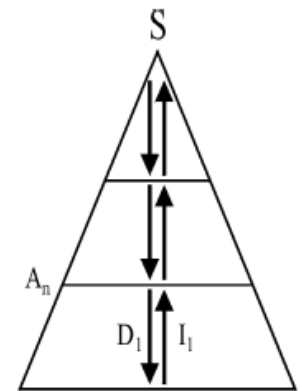

Comprising the state monopolized economic sub-field

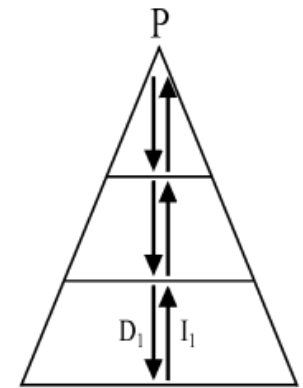

Comprising the monopolized political sub-field

\subsection{The second, intertwined layer}

An augmented network evolves through the second layer, as the party, originally one entity in one subfield (political) monopolizes its own sub-field and stretches out its instruments of power to other sub-fields, permeating the boundaries of non-party organizations, and overlapping the decision-making process through positional structure (nomenklatura responsibility), activity structure (subject matter responsibility), organizational structure (instructor system) and individual decision-makers (party discipline of party members). ${ }^{2}$ Figure 2 depicts the augmented network that incorporates the first one with the directions of dependencies providing the multiple ways and interest promotion.

Figure 2 The second layer: the augmented network through the interlinking threads and varieties of interest promotion

\footnotetext{
${ }^{2}$ Instruments of party power and their functions are detailed in Csanádi, 1997.
} 
Key:

$\begin{array}{ll}S & \begin{array}{l}\text { State (non-party) } \\ \text { hierarchy }\end{array} \\ \mathrm{P}_{\mathrm{n}} & \begin{array}{l}\text { Party hierarchy } \\ \text { Decision-makers (actors) } \\ \text { at the } \mathrm{n}^{\text {th }} \text { level of the } \\ \text { structure }\end{array} \\ \mathrm{D}_{1} \quad \begin{array}{l}\text { Direction of intra- } \\ \text { hierarchy } \\ \text { dependence }\end{array} \\ \mathrm{D}_{2} \quad \begin{array}{l}\text { Direction of cross- } \\ \text { hierarchy } \\ \text { dependence }\end{array} \\ \mathrm{I}_{1} \quad \begin{array}{l}\text { Path of intra-hierarchy } \\ \text { interest promotion } \\ \text { Path of cross-hierarchy } \\ \text { interest promotion }\end{array} \\ \mathrm{I}_{2} \quad \frac{1}{}\end{array}$
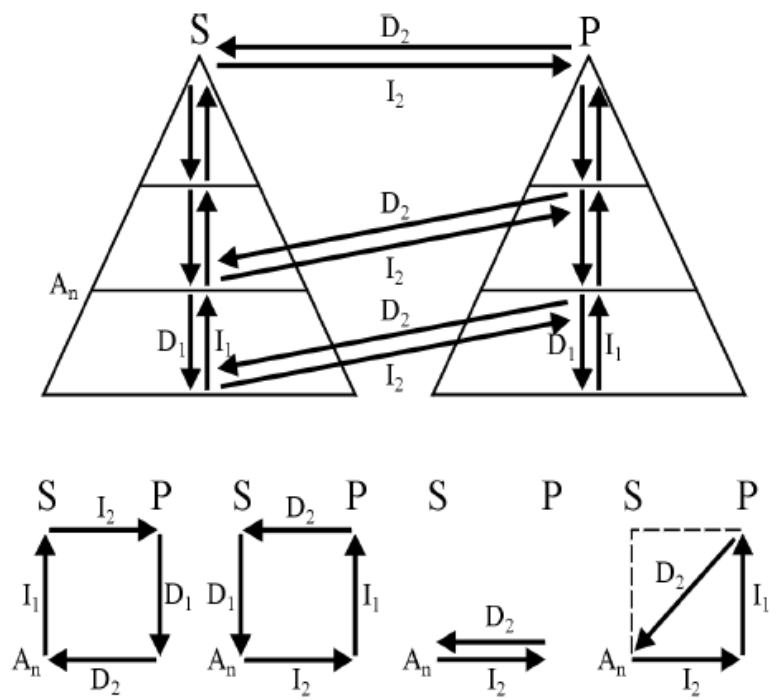

a.

h.

C.

d.

In the augmented network, actors attached to interlinking lines are dependent on as many of the ways expectations or orders run through the channels of different power instruments of the party and the hierarchy. But, at the same time, interlinking dependency lines multiply the chances for interest promotion in as many directions as dependency lines are held in the party hierarchy, and allow circumvention of the actors' own hierarchy in several modes (see a., b., c., d. versions on Figure 2).

Figure 3 looks into the same subject in more detail and is based on empirical research done in Hungary in the 1970s and 1980s. The sketch contains the organizations within both hierarchies and the different power instruments that interlink those from the party hierarchy. Room for manoeuver in this figure depends on the number of interlinking lines attached to the actors: the more interlinking line an actor is attached to, the larger the dependency, and the larger the actor's options for maneouvering. Consequently, interlinking lines not only allow larger room for manoeuvre by circumventing direct subordination and multiplying channels of interest promotion, but also introduce structural inequalities in bargaining capacities among actors of the same level in the hierarchy depending on the number and strength of interlinking 
lines attached to the actor. Through interlinking lines direct sensitivity evolves towards those at both ends of the channel: decisons taken in the party hierarchy may directly stabilize or destabilize actors in the economic subfield, while decisions in the non-party hierarchy may quickly stabilize or destabilize the political sub-field. Lines on Figure 3 are not expected to be followed by the reader, instead Figure 3 is just an empirical example to demonstrate the sheer complexity and obscurity of the network even in its schematic simplified form.

\section{Figure 3 The hierarchical and the interlinking lines of dependencies and interest}

\section{promotion (traced empirically in Hungary)}

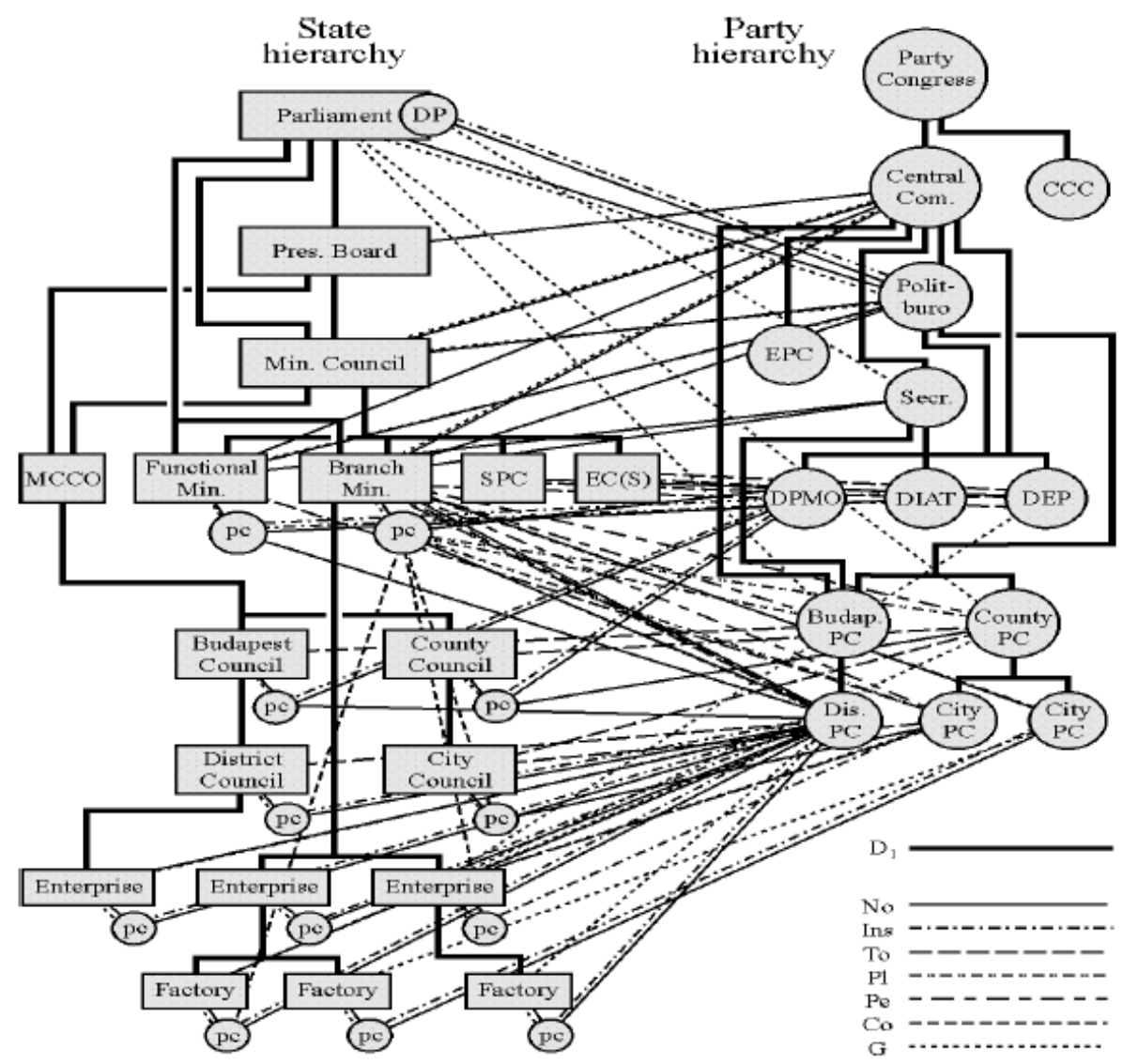

Note: hierarchical (D1) lines within party and state hierarchy; interlinking (D2) lines as instruments of Party power: No nomenklatura responsibility; Ins instructor system To subjectmatter (topic) responsibility system; Pl party liaison system: coordination and consultation between branch ministries and local party organizations; Pe connections of party organizations in enterprises with the Personnel Department of the branch ministries concerning cadre issues Co regular consultation between enterprise pc and ministry pc; $\mathrm{G}$ interventions in the name of general economic policy responsibilities of the party; DP 
deputies in the Parliament with party membership; PC local party committees; pc party committees within organizations; CCC central controling committee; EPC Economic Policy Committee; DPMO Department of Party Mass Organizations; DIAT Department of Industry, Agricultureasn transportation; DEP Department of Economic Policy; MCCO Ministerial Councils' Council Office; SPC State Planning Office; EC(S) Economic Committee of the State

\subsection{The third intertwined layer: shortcuts in the network}

The augmented network is strengthened by a third type of networks; the network of shortcuts (Figure 4), that complements and incorporates the previous two layers and can efficiently influence the decision-making process $\left(\mathrm{I}_{3}\right)$. Shortcuts will evolve into structural feedback loops within hierarchies through $\mathrm{D}_{1}$ dependency lines, or across hierarchies through $\mathrm{D}_{2}$ dependency lines (Figure 4) during the decision-making process. ${ }^{3}$ Structural feedback loops will introduce new structurally built-in inequalities in the capacity to promote interests "on the spot". This is because short-cuts allow privileged actors to communicate with decision-makers whom otherwise would never meet given the difference in the level of their formal position in the hierarchy.With short-cuts they may directly acquire and forward information that otherwise would be impossible or only achieved through mediators. They may look into documents they would otherwise never access, meet higher level decisionmakers on party and state hierarchies

\footnotetext{
${ }^{3}$ Short-cuts may occur occasionally e.g. an enterprise manager is invited to a ministerial level session where export strategy is developped as an important exporter to the Soviet Union, he may be part of the delegation of bilateral bargaining with the Soviet Union, or a strategic exporter to the West. Short-cut may be formed also for longer term, such as being appointed as key enterprise of long-term technical development programs, or providing pre-plans for the medium or long-term national plan, or if they are important enterprises appointed for closer statistical monitoring by the central government or be elected to the sub-national (district, city, county or province) level party executive (standing) committee, or that of the Central Committee.
} 
they would never meet,or participate in decisions they would otherwise never be able to.

Consequently, through structural feedbacks actors become able to directly and efficiently influence those decisions that would affect them, accumulate further connections and feedback, attract new resources, resist interventions or prepare for the unavoidable decisions, both within their own hierarchies and across the party hierarchy. Chances for short-cuts however are not uniform, this is the privilege of the few whose properties and instability can provoke higher political sensitivity of those holding the dependency lines in both hierarchies.

Figure 4 The third type of linkages: the structural feedbacks (shortcuts) and varieties of interest promotion

\begin{tabular}{|c|c|}
\hline \multicolumn{2}{|l|}{ Key: } \\
\hline $\mathrm{S}$ & $\begin{array}{l}\text { State (non-party) } \\
\text { hierarchy }\end{array}$ \\
\hline $\mathbf{P}$ & Party hierarchy \\
\hline$A_{n}$ & $\begin{array}{l}\text { Decision-makers (actors) } \\
\text { at the } \mathrm{n}^{\text {th }} \text { level of the } \\
\text { structure }\end{array}$ \\
\hline$\partial_{1}$ & $\begin{array}{l}\text { Direction of intra- } \\
\text { hierarchy dependence }\end{array}$ \\
\hline 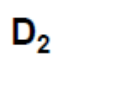 & $\begin{array}{l}\text { Direction of cross- } \\
\text { hierarchy dependence }\end{array}$ \\
\hline & $\begin{array}{l}\text { Path of intra-hierarchy } \\
\text { interest promotion }\end{array}$ \\
\hline & $\begin{array}{l}\text { Path of cross-hierarchy } \\
\text { interest promotion }\end{array}$ \\
\hline & Direction of feedbacks \\
\hline
\end{tabular}

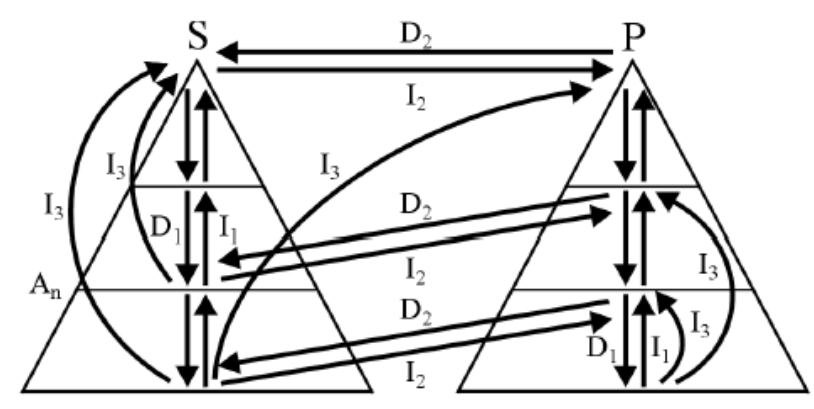

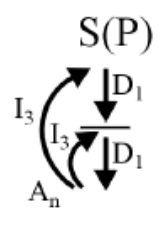

a.

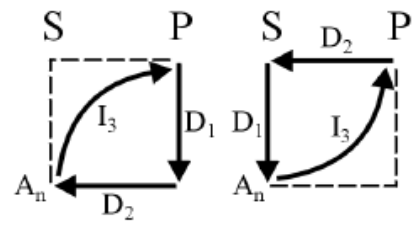

$h$.

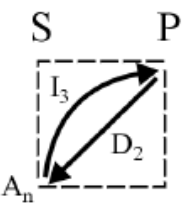

d.

\subsection{The complex network of party-states}

With the three layers that mutually incorporate each other, a complex party-state power network is formed (Figure 5). Elements of this network are: the Party hierarchy, monopolizing the political sub-sphere, the state hierarchy, monopolizing the non-party sub-fields, including 
the economy, and thereby monopolizing the extraction and distribution of resources and the instruments serving those; the interlingking lines directly through the party, or indirectly through the state, politically monopolizing dependencies and interest promotion $\left(\mathrm{I}_{2}\right)$ and the feedback loops $\left(\mathrm{I}_{3}\right)$, both providing structural inequalities in interst promotion and in resource extraction and distribution. Thus, owing to $\mathrm{I}_{2}$ and $\mathrm{I}_{3}$, formal position in the hierarchy and bargaining position in the complex network differ. The network has closed channels and actors can efficiently utilize their channels individually that leads to atomization, i.e., to nonsynchronized dependency and interest promotion. Consequently, actors' bargaining capacities are obscure and can change quickly if their shortcuts or interlinking lines undergo change. In other words, behind each actor there is an indeterminate "phantom force" about which the partner can only guess (Csanádi, 1997, 30). In this network dependencies are unidirectional, but multi-threaded and so are the channels for the promotion of interests. At the same time, direct connections of party and non-party actors mantain high sensitivity to each others' decisions. No matter the complexity and obscurity of the network, principles of connection are simple: (1) interlinking lines may only origin in the party hierarchy since they are instruments of party power held by actors in the party hierarchy; (2) therefore, feedback across state and party hierarchy may only originate in the state hierarchy since the loop is formed by the interlinking threads that originate in the party hierarchy. 
Figure 5 The complex network of party-states and varieties of interest promotion

\begin{tabular}{|c|c|}
\hline \multicolumn{2}{|l|}{ Key: } \\
\hline s & $\begin{array}{l}\text { State (non-party) } \\
\text { hierarchy }\end{array}$ \\
\hline $\mathbf{P}$ & Party hierarchy \\
\hline$A_{n}$ & $\begin{array}{l}\text { Decision-makers (actors) } \\
\text { at the } \mathrm{n}^{\text {th }} \text { level of the } \\
\text { structure }\end{array}$ \\
\hline $\mathrm{D}_{1}$ & $\begin{array}{l}\text { Direction of intra- } \\
\text { hierarchy dependence }\end{array}$ \\
\hline $\mathrm{D}_{2}$ & $\begin{array}{l}\text { Direction of cross- } \\
\text { hierarchy dependence }\end{array}$ \\
\hline$I_{1}$ & $\begin{array}{l}\text { Path of intra-hierarchy } \\
\text { interest promotion }\end{array}$ \\
\hline $\mathrm{I}_{2}$ & $\begin{array}{l}\text { Path of cross-hierarchy } \\
\text { interest promotion }\end{array}$ \\
\hline & Direction of feedbacks \\
\hline
\end{tabular}
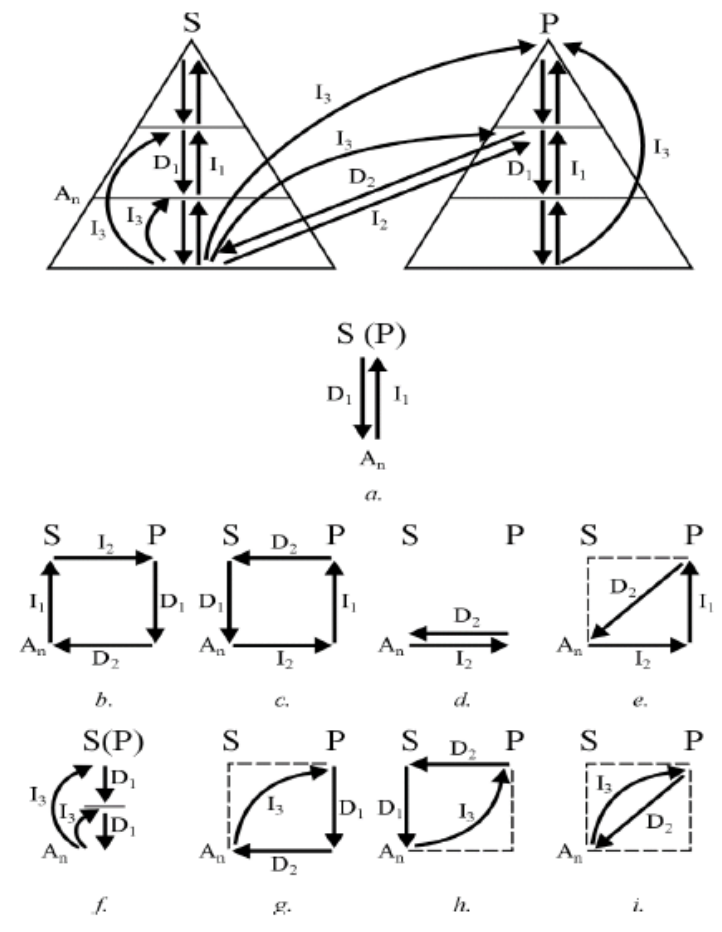

\section{The operation of party-states}

\subsection{The principles of operation and their dynamics}

Elements and principles of connection will bring about characteristic principles of operation:

since all actors have $\mathrm{D}_{1}$ lines, but only party actors have $\mathrm{D}_{2}$ lines interlinking all others in other subfields, dependencies and interest promotion as well as resource extraction and distribution are directly or indirectly (through state hierarchy) politically monopolized.

In this politically monopolized structure actors are in a dual position: They are simultaneously holders of and captured by dependency lines, thereby incorporating two functions: distributors 
and pleaders in one single entity. ${ }^{4}$ As monopolistic holders of the lines, they are able and simultaneously forced to intervene - otherwise losing bargaining position; As embraced by these lines they are exposed and simultaneously interested in keeping and multiplying dependency threads for interest promotion and in exchange accommodate to expectations otherwise losing bargaining position. Capacity and force, exposure and interest together ensure the politically rational motivations of economic behavior for self-reproduction and thereby the cohesion and reproduction of the whole network.

Owing to the actors' dual position and functions the capacity for self-reproduction is complex. One single actor as holder (intervener) of the lines has resource extracting and redistributing capacity and as embraced by those (pleader), has resource attracting and resisting capacities to interventions. These capacities together will provide the constraints of self-reproduction of an actor. However, capacities and constraints of self-reproduction are not uniform but selective: positional differences due to built-in inequalities - interlinking lines $\left(D_{2}, I_{2}\right)$ and feedbacks $\left(I_{3}\right)$ - will forge selective chances (capacities) for resource attraction, extraction, allocation and resisting interventions. Consequently, actors' selective chances according to structural bargaining capacities lead to selectively soft or hard constraints of self-reproduction.

Selectively soft and hard chances for self-reproduction challenge Kornai's widely accepted paradigm on generally soft budget constraint of enterprises in communist systems (Kornai, 1980, 1992, Kornai et al. 2003). Since in case we nest budget constraints in the politically monopolized network of power relations, budget constraints prove to be selectively soft rather than generally soft. The validity of this argument no matter the space, time and different levels of aggregation is supported both by statistical analysis of manufacturing enterprises on a national level in Hungary during 1970-1979 Csanadi, 1997) or in China in 2008-2011

\footnotetext{
${ }^{4}$ This argument counters Kornai's where pleaders (enterprises) and distributors (paternalistic state) are separate entities (Kornai, Maskin, Roland 2003).
} 
among manufacturing enterprises at city level (Csanadi and Liu, 2012) or by their promotion internationally (Nolan, 2014). According to the surveys, the chances of being privileged radically increase the larger the enterprise at national and/or local level, the more integrated into the network and in the Chinese case, if characterized by state ownership. This distribution characteristic will have crucial consequences on actors' behavior and on the reproduction of the whole system. It will bring about politically rational fixed paths of resource distribution; politically rational selectively soft reproduction constraints, and will conclude in politically rational motivations of economic behavior: the striving for growth, for resources and for cummulated integration (accumulating interlinking lines I2 and feedbacks I3) into the decision-making network and political adaptation in order to achieve this goal. These circumstances assign a structural motivation and system characteristics to actors' behavior rather than relying on the "natural instincts" of enterprise managers for growth and power argued by Kornai (1980, pp. 78, 204-206). The steady structural motivations for growth and thereby to reproduce and improve bargaining capacity to be further privileged, and the repeated allocation of resources according to politically rational rather than economically rational criteria render fixed paths of resource distribution and forge the structural and motivational reasons of overcapacity and investment overheating. These characteristics will lead occasionally to hard reproduction constraints of the whole network ending up in repeated investment cycles.

\subsection{Political concerns versus economic efficiency in the network}

We may conclude from the analytical description so far that both structure and operation are based on political concerns: the rationale of connecting subfields, the instruments for connection and the concerns of in-built inequalities. Based on the politically constructed network, so tofactors of self-reproduction of the structure are politically motivated as are the 
principles of operation; dependencies, interest promotion and resource distribution; the criteria of selection and, based on that, the fixed paths of resource distribution, the selectively soft/hard reproduction constraints and the politically rational economic motivation and behavior (accumulating feedbacks and drive for growth). In sum, the reproduction of the whole network is politically motivated. In this politically motivated structure and operation economic efficiency constraints and motivations for efficiency in self-reproduction will be lacking both individually and for the whole structure. Instead, structural constraints - that is, the given distribution of power (atracting and resisting, extracting and allocating capacities) determines the hardness or softness of reproduction constraints, both for individuals, units and the net as a whole. Thus, since economic behavior is politically rational instead of economically and power distribution rather than economic efficiency determines the hardening constraints of self-reproduction, the process of self-reproduction in the long-term leads to self-consumption - in other words, to transformation. ${ }^{5}$

\subsection{Sensitivity to external dynamics: the interplay of external and internal constraints}

Efficiency constraints external to the network and specific structural (reproduction) constraints internal to it are strongly interdependent through the dynamics within and outside the network. If efficiency (budget) constraints are soft (e.g. external loans and FDI flow easily, competitive pressures are low, export demand is high and import conditions are favorable), resources entering the network from outside of it are flexibly "form-fitted" according to power relations. Thus reproduction constraints remain soft and soft external

\footnotetext{
${ }^{5}$ The logic of this process was analyzed in the case of the Soviet Union when the Eastern Bloc turned from an asset into a devastating liability to the Soviet Empire leading to possible self-consumption which was described by Bunce (1984/1985), years ahead of the collapse of the Soviet Bloc.
} 
constraints contribute to the conservation and reproduction of the given power relations.

These conditions prevail until efficiency constraints exerted by the external environment and reproduction constraints defined by internal power distribution are soft for self-reproduction. If structural constraints in self-reproduction are met and resources from higher aggregation levels flow poorly, structural constraints become hard and exposure to external factors arise and the importance of external constraints exerted from outside the net emerges. When both external and structural constraints become hard, adaptation pressures and drives intensify (Csanádi, 2013). ${ }^{6}$

\section{The common grounds of party-states: the self-similarity in the IPS model}

Concluding the above, we now may define the concept of party-state systems based on the IPS model by combining its structural and dynamic characteristics. The party as one political entity in one sub-field (political), by monopolizing the political subfield and the non-party subfields via its instruments of power, evolves into a politically monopolized institutional power structure embracing and infiltrating all other sub-spheres of the society structurally determining its inequalities. The politically monopolized power structure of party-state systems should not be interpreted as monolithic. Oppositely, this paper demonstrates its very internal subtleties: the network, its elements, connecting and operating principles, the closed channels, the phantom force behind actors during bargaining, the different interests, different

\footnotetext{
${ }^{6}$ The stimulus package introduced in late 2008 in China was the direct adaptive consequence of an external shock (hard constraint) caused by the global crisis and the subsequent internal government reaction in the form of intensified state intervention that mobilized economic actors (Yu, 2010; Wong, 2011). New chances for resource distribution have mobilized characteristic distribution priorities and enterprise behavior in the system according to the ownership, size and extent of integration of economic units into the network leading to investment overheating and local indebtedness (Yu,2014).
} 
dependencies, the politically rational economic behavior, the politically rational selection, its structural inequalities, the changing dynamics of bargaining capacities ${ }^{7}$.

In this social system, no matter the time, the space or the level of aggregation of the elements, the connecting and operating principles and the political concerns of building the structure as well as its structural and dynamic consequences are self-similar (Csanadi, 1997, 2006, 2011). Self-similarity in mathematics is the alternative concept of "fractal".

"A fractal is a natural phenomenon or a mathematical set that exhibits a repeating pattern that displays at every scale. It is also known as expanding symmetry or evolving symmetry. If the replication is exactly the same at every scale, it is called a self-similar pattern... Fractals can also be nearly the same at different levels. This latter pattern is illustrated in the magnifications of the Mandelbrot set. Fractals also include the idea of a detailed pattern that repeats itself'.( https://en.wikipedia.org/wiki/Fractal). The concept was adapted to natural phenomena by Mandelbrot (1983) who discovered "fractal" properties - self-similar structural patterns - in nature. Encouraged by empirical findings, I have adapted fractal, or self-similar, properties in political economy to describe the essential characteristics of communist systems in the IPS model. I further developped the consequences of fractal properties as self-similar structural dynamics within the model. Thus, the concept of self-similarity became one of the most essential statements of this study as these characteristics render the common basis of

\footnotetext{
${ }^{7}$ This systemic characteristic in China becomes even more entangled with the multiple, occasionally active and partially overlapping societal networks at different cross sections of society (guanxi) - from revolutionary period to schools, neighborhoods, prior workplaces etc. - that weave through the systemic network and mutually utilize opportunities.
} 
comparison of party-state systems at different level aggregations, in space among countries, or provinces, or cities and in different times of their existence ${ }^{8}$.

If so many factors contribute to self-similarities and these prevail in time, space and levels of aggregation then why did and do party-states operate and transform so differently?

\section{The structural background of the differences}

\subsection{Varieties of power distribution}

The IPS model offers a comprehensive explanation of the varieties of party-state systems based on the persistence of self-similarities. With a more thorough look at the self-similar elements of the structure, one discovers that the origin, outreach, distribution, accumulation, and extension of these elements may vary in time, in space and at different levels of aggregation while principles of connection and operation of the system and their structural consequences remain constant. It is the strictness and depth of $\mathrm{D}_{1}$ lines in both hierarchies, the level of centralization or decentralization of the gradual expansions over interlinking lines along the party hierarchy, the level of centralization or decentralization of the discretion over resource extraction and allocation along the state hierarchy and the density, accumulation, level of origin and arrival of feedbacks in the party or state hierarchies and across hierarchies (Csanádi, 2006). Taking all together, the combination of the variations of the structural elements will present the innumerous variety of power distribution. Differences occur both in time (e.g. Hungarian power distribution before and after 1956 revolution), in space (e.g. the Romanian and Chinese power patterns in the 1980s) and and at different level aggregations

\footnotetext{
${ }^{8}$ The IPS model's self-similarity concept was one of the key explanatory factors applied by Bunce (1999) to describe the design and destruction of socialism and the state in the Soviet Union, Czechoslovakia and Yugoslavia.
} 
(e.g. initiated, but not universally completed half-way local elections at village level and in constrained number and procedures at township level in China in 1990s (Lai, 2004).

Varieties of power distribution involve different extents and distributions of resisting and resource attracting capacities of actors within the network; different frequency of meeting hard constraints of self-reproduction of the structure as a whole, instruments of resource extraction and distribution, ways of self-reproduction, paths of transformation and different outcomes.

\subsection{Patterns of power distribution and their dynamics}

Differences may be grouped into three characteristically different patterns of power distribution: the Self-exploiting, Self-disintegrating and Self-withdrawing patterns (Table 1). The names suggest the networks' structural and operational traps that lead to system transformation.

Within those patterns a wide variety of structures may be found but with the same main pattern characteristics. The table is composed according to the structural characteristics and the dynamics these characteristics incite. The pattern of power distribution, the instruments of resource extraction and distribution of the given pattern allows as a result of the actors' resisting and resource attracting capacities that will determine the frequency the whole pattern meets, hardening reproduction constraints that invite new pattern-conforming measures that result in characteristic ways of development and transformation.

\section{Table 1 Main patterns of power distribution}




\begin{tabular}{|c|c|c|c|}
\hline TRAITS & $\begin{array}{l}\text { SELF-EXPLOITING } \\
\text { (e.g. Romanian, North } \\
\text { Korean and all initial) }\end{array}$ & $\begin{array}{c}\text { SELF-DISINTEGRATING } \\
\text { (e.g. Hungarian from } 1956 \\
\text { onwards) }\end{array}$ & $\begin{array}{l}\text { SELF-WITHDRAWING } \\
\text { (e.g. Chinese from } 1979 \\
\text { onwards) }\end{array}$ \\
\hline Distribution of power & $\begin{array}{l}\text { Centralized extraction } \\
\text { and distribution, } \\
\text { centralized interlinking } \\
\text { threads, few feedbacks }\end{array}$ & $\begin{array}{l}\text { Centralized extraction and } \\
\text { redistribution, centralized (or } \\
\text { decentralized) inter-linking } \\
\text { threads with strong economic } \\
\text { feedbacks }\end{array}$ & $\begin{array}{l}\text { Partially decentralized } \\
\text { extraction and redistribution } \\
\text { and either centralized or } \\
\text { decentralized inter-linking } \\
\text { threads with economic } \\
\text { feedbacks }\end{array}$ \\
\hline $\begin{array}{l}\text { Bargaining capacities } \\
\text { of actors in the } \\
\text { network }\end{array}$ & $\begin{array}{l}\text { Faint attracting and } \\
\text { resisting capacity }\end{array}$ & $\begin{array}{l}\text { Selectively strong } \\
\text { attracting and resisting capacity }\end{array}$ & $\begin{array}{l}\text { Selectively strong } \\
\text { attracting and resisting } \\
\text { capacity, owing to feedbacks } \\
\text { and dec. alternative resources }\end{array}$ \\
\hline $\begin{array}{l}\text { Constraints } \\
\text { of self-reproduction }\end{array}$ & Rarely hard & Occasionally hard & Frequently hard \\
\hline $\begin{array}{l}\text { Modes of resource } \\
\text { extraction }\end{array}$ & $\begin{array}{l}\text { Forced resource } \\
\text { redeployment }\end{array}$ & $\begin{array}{l}\text { Resource mobilizing } \\
\text { (decentralizing) reforms within } \\
\text { the network }\end{array}$ & $\begin{array}{l}\text { Resource mobilizing and } \\
\text { resource creating reforms } \\
\text { within and outside the network }\end{array}$ \\
\hline $\begin{array}{l}\text { Economic } \\
\text { development }\end{array}$ & $\begin{array}{l}\text { Forced growth of heavy } \\
\text { industry to physical } \\
\text { boundaries }\end{array}$ & $\begin{array}{l}\text { Economic recession and reform } \\
\text { escalation within the network }\end{array}$ & $\begin{array}{l}\text { Economic growth outside the } \\
\text { net, recession within the net } \\
\text { and reform escalation outside } \\
\text { the network }\end{array}$ \\
\hline $\begin{array}{l}\text { Legitimacy and } \\
\text { retreat }\end{array}$ & $\begin{array}{l}\text { Tensions growing, no } \\
\text { retreat, abrupt collapse }\end{array}$ & $\begin{array}{l}\text { Party legitimacy declining, } \\
\text { relative and absolute gradual } \\
\text { retreat from political sub-field }\end{array}$ & $\begin{array}{l}\text { Party legitimacy kept, relative } \\
\text { and absolute gradual retreat } \\
\text { from economic sub-field }\end{array}$ \\
\hline
\end{tabular}

According to Table1, Self-exploiting pattern is characterized by the centralized origin of interlinking threads in party hierarchy, centralized discretions of resource extraction and distribution in state hierarchy, and weak and scarce feedbacks from the economic sub-field. This pattern was characteristic to any party-state in the 1950s and still applies to North Korea (Szalontai and Choi, 2014). Here resisting capacities are low, the system may reproduce itself through forced resource redeployment until the physical capacities of society and the reproduction of the whole system rarely meets hardening structural constraints, while tensions may mount high in the society. If this pattern meets hardening structural constraints, external resources may substitute internal resources for self-reproduction, or new forced resource redeployment is implemented through redistribution of power. If both external and internal constraints become hard, pattern-conforming measures escalate until there is sudden collapse. (2) In the Self-disintegrating pattern, interlinking lines in the party hierarchy are relatively centralized, resource extraction and distribution is centralized while feedback is strong. This pattern evolved in Hungary after the transitory collapse of the Self-exploiting pattern in 1956, or during Brezhnev's reign, following the chaos in the self-exploiting pattern and 
destabilizing power struggles after Stalin's death and Khrushchv's activity and demotion. In this pattern, resource attracting and resisting capacities are strong and efforts for forced resource redeployment are inefficient (form-fitted). In order to keep the pattern's cohesion different types of resource extracting and distributing measures are needed. Decentralizing reforms within the network are introduced that provide the pattern-conforming instruments for self-reproduction. However, owing to the higher resisting capacities of those with feedback, their incessant politically rational motivations for growth and the political rationality of selective distribution, reproduction of the pattern meets hardening structural constraints more frequently than the centralized pattern. Until external sources flow the system form-fits those to the given pattern distribution without the need for changing status quo. However, if both external and structural constraints become hard, this brings about decentralizing reform escalation within the network without efficiency increase, causing recession spiral, loosening cohesion or the network, and declining party legitimacy and thereby political transformation first.

(3) In the third, Self-withdrawing pattern origin of interlinking threads is relatively decentralized in the party hierarchy. So is the capacity for resource extraction and distribution, while also feedback i strong. ${ }^{9}$ This pattern evolved in China during Mao's repeated decentralizing campaigns (through forced resource redeployment) when also centrally subordinated state owned enterprises were delegated under different local levels of the state and party hierarchy, temporarily disrupting the self-exploiting pattern to annihilate potential competitors to his power in the center. By the time Deng Xiao Ping took power, this decentralized power structure stabilized and institutionalized.

\footnotetext{
${ }^{9}$ The prevalence of this distribution of power to date in contemporary China is indirectly supported by Lin, (2011), Szamosszegi and Kyle (2011) and Khoo (2012) in their analysis on the institutional structure and control of state-owned enterprises.
} 
Since exposure to central resource distribution in this pattern is weaker, while resisting and resource attracting capacity is stronger, neither forced resource redeployment, nor decentralizing reforms provide sufficient resources for the center to reproduce the system. Both forced resource redeployment and decentralizing reforms are form-fitted. In other words, Deng's decentralizing reforms only further increased the decentralized character of the power structure. Owing to structural specifics the pattern meets hardening constraints of selfreproduction and loss of cohesion of the structure even more frequently than the other two. In the loss of cohesion new pattern conforming measures are born by leaping out of the structure and allowing the competitive field to expand that provides growing external resources for the reproduction of the pattern. The gradual expansion of the economic field external to the network is the structural reason why in this pattern economic transformation comes first (see Csanádi 2006, 73-355).

\subsection{Changes within patterns, pattern shifts and internal and external dynamics}

Patterns may reproduce themselves in roughly the same power distribution but also changes to different extent in the distribution of power may occur (i) within patterns, bargaining capacities reflected by the distribution of power may vary in time, in space, and at different levels of aggregation of the network, while the network itself keeps its main pattern characteristics. (ii) However, if the main pattern characteristics change, the pattern itself will change. ${ }^{10}$ Pattern shifts need transitory collapse, but not all collapses conclude in pattern shift,

\footnotetext{
${ }^{10}$ In China, pattern shift was caused by Mao Zedong's repeated decentralization campaigns that resulted in temporary collapses of the self-exploiting pattern. By the time Deng Xiaoping took over the power, the episodically evolving pattern shift finally stabilized in the selfwithdrawing pattern of power distribution. In Hungary, pattern shift from self-expoliting to Self-disintegrating occurred after the temporary system collapse during the 1956 revolution.
} 
as patterns may regenerate in the original form (iii) If the main structural elements, connecting and operating principles that compose the system wane, system transformation will occur in those patterns.

As we have argued, changes in the patterns are strongly intertwinded with internal and external dynamics. ${ }^{11}$ Different patterns are differently sensitive and resistant to external and internal pressures (shocks), be these simultaneous or alternative. In case of external constraints being soft while structural constraints become hard, no adaptation pressures emerge: reproduction constraints remain soft in all patterns. In the case of external constraints becoming hard, adaptation and instruments of adaptation to external pressures are patternconforming. Sensitivity of patterns is reflected in the responsiveness to the pressures for adaptation to external and internal shocks. The pattern will determine the resisting capacity of actors against increased internal resource extraction in case of hard external resource constraints: the lower the capacity to resist, the higher the capacity to extract further resources from within. From this point of view, structurally the least sensitive is the self-exploiting, the most sensitive is the self-withdrawing pattern.

External and internal shocks may prevail for different periods. Thus, not only pattern differences but also the varying time-span of the impact will influence sensitivity and

\footnotetext{
${ }^{11}$ External pressures from the point of view of the system's operation are for example the death of Stalin in 1953, the domino collapse of the European communist systems in 19891991, for China and Vietnam, the Asian crisis at the end of the 1990s, or the global crisis by the end of 2008. Internal shocks are for example: the death of the country's authoritarian leader as of Gheorghiu-Dej in Romania in 1965, or that of Mao in 1976; Mao's decentralization campaigns during his reign; popular uprisings in the early and mid-1950s in Eastern European party-states and the Tiananmen Square events in China in 1989; or the periods of dramatic shortage of resources to distribute within the network.
} 
responsiveness, defining adaptation. Differences in the sensitivity and responsiveness to external and internal adaptation pressures emerge not only in time or according to time-span, but also in space and among different aggregation levels. All these impacts may occur at different stages of operation of the system: both during the period of self-reproduction, when main system and pattern characteristics prevail, and during sytem transformation, when system and pattern characteristics gradually wane while the main traits of another system emerge. Adaptation may end in the restructuring of power relations without changing patterns (regeneration). They may also conclude in changing patterns or may also lead to transformation. According to the model and historical experiences, regeneration of the system is allowed if only one, either external or internal reproduction constraint of the system gets hard, while the other remains soft. Pattern shifts occur when simultaneous external and internal pressures force the collapse of the system, but pressures last for a short period, and, therefore, collapse is temporary and regeneration is possible. Historically, we only have examples for a shift from the self-exploiting pattern to self-disintegrating and selfwithdrawing ones. Independent of pattern characteristics, transformation is likely to begin when both external and internal constraints become hard and they persist for a longer time, but reactions are pattern conforming: escalation of pattern-conforming instruments, leads to pattern-conforming transformation.

\section{Pattern-conforming system transformations}

\subsection{Transformation dynamics}

System transformation is a qualitative process when so far dominant structural and operating principles, selection criteria and actors adapting behavior become irrelevant and different operating principles and selection criteria and according behavior become dominant. The systemic transformation process evolves as the party-state network retreats as a social system from monopolized political, economic sub-spheres, and the sub-spheres of a new social 
system emerge outside of the network. System transformation is a process that has its time sequence. Owing to structural characteristics of the network, sub-fields transform one-by-one or simultaneously. If one-by one, there is a structural order in the sequence: it is patterndependent which subfield comes first and which follows. Time-lag between the transformation of sub-fields varies: sub-field transformations may somewhat overlap or follow consecutively but the transformation of the next subfield to follow may also freeze for an indefinite time. Therefore, system transformation might halt and remain even "incomplete".

Transformation may be absolute, when physical changes in the network occur: bargaining activity through the channels declines (the network is emptied), or the network is weakened, constrained, or cut off. Transformation may also be relative, when retreat and expansion acquire different speed or both fields expand but with different speed. Transformation may slow down if instead of retreat, the network expands either absolutely or relatively. The dynamics of relative or absolute retreat and emergence develop in strong interaction. Variations in the absolute and relative dynamics of transformation and their combinations will present different types of transformation dynamics that may show different spatial configurations at different levels of aggregation.

However, no matter the pattern, the process of transformation is not a continuum in direction or speed: it may speed up, slow down and even temporarily reverse under alternative or simultaneous external and internal pressures of adaptation. ${ }^{12}$ The dynamics of transformation

${ }^{12}$ Empirical reseach results reveal that despite China's substantial transformation towards a market economy, the occasional need for increased state intervention has mobilized the characteristics of the party-state system at all aggregation levels temporarily increasing the expansion of the network (Csanádi, 2013). 
may change temporarily in space, in time and among different aggregation levels, and may influence the interrelated dynamics of absolute and relative transformation. The higher the resisting capacity of actors, the more frequent the occasions of hardening constraints of selfreproduction of the system and the stronger is the escalation of pattern-conforming instruments during adaptation that contribute to the evolution of system transformation. The higher the frequency of meeting hardening constraints the more gradual the transformation process through adaptation will be. Conversely, the lower the resisting capacity, the less frequently the system meets hard constraints of self-reproduction inciting adaptation, the more abrupt the initials of transformation will be since adaptation was not necessary. The same structural reasons will contribute to different systemic outcomes (Bunce, 1999; Bohle \& Greskovits, 2012). Uncertainties during transformation in all patterns are cumulated (Bunce and Csanádi, 1993). What differs is the level, intensity and persistence of cumulated uncertainty and the predictability of outcome. In countries where a Self-exploiting pattern suddenly collapsed cumulated uncertainties are higher, last longer and outcomes are less predictable and in a longer spectrum (see from Romania to Kirgiztan) than at countries in the context of the other two patterns.

Different transformation dynamics are influenced by multiple individual historical, cultural, economic and geopolitical factors but have also multidimensional system-conforming factors that interplay with those. This may include: differences among patterns, differences within patterns, differences due to the density and strictness of connections between aggregation levels and the different dynamics of the external environment. All these individual, structural characteristics and timings will influence the differences in the sequence (first economic or political, or simultaneous), speed (gradual or abrupt) and conditions of transformation (economic transformation under authoritarian or democratic rule, accompanied by 
macroeconomic growth or decline). Sequence, speed and conditions however are not issues of strategic choice but instead are defined by structural constraints.

\subsection{Examples for pattern-conforming transformation dynamics and components of retreat and emergence}

Below we shall roughly detail the sequence, speed and conditions in the process of transformation according to the three main patterns of power distribution. Figure a reflects the pattern-characteristics of the sequence, speed and conditions transformation, while Figure b highlights the elements of retreat of the network and Figure $\mathrm{c}$ the factors of the emergence of the new sub-field outside the network. Gray arrows represent the different factors of retreat in political and economic subfileds (decentralization, cut-off, withdrawal, and strip of) while black arrows depict the emergence of the elements of the new economic and political subfields in a cumulated process.

Figure 6 depicts the characteristics of the Self-exploiting pattern. However, in this case the a, $\mathrm{b}$, and c figures are merged since due to the abrupt collapse of the network infiltrating all subfields, transformation of the various fields is overlapping and the sequence is hard to define. In this pattern political and economic outcomes of the system transformation are uncertain, factors of retreat and emergence are indiscernible, while the macroeconomic crisis is deep and long. Moreover, due to the abrupt collapse of the network, transformation of the various fields overlaps, absolute and relative retreat is taking place simultaneously and alternatively in each subfield, composing elements (factors) of retreat and expansion at each sub-field are indiscernible, the level of cumulated uncertainties is high, aggravated by the deep and long-lasting macroeconomic crisis. Thus, both sequence and outcome of system transformation is hard to define. Therefore, in the case of the Self-exploiting pattern the figure 
is not separated into a, b, and c as it contains them all simultaneously, with the resulting cumulated uncertainties.

Figure 6. Nature of system transformation in the Self-exploiting pattern

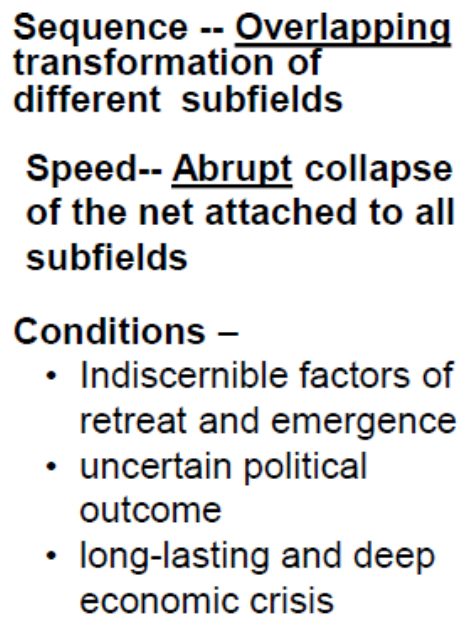

- Indiscernible factors of retreat and emergence

- uncertain political outcome

- long-lasting and deep economic crisis

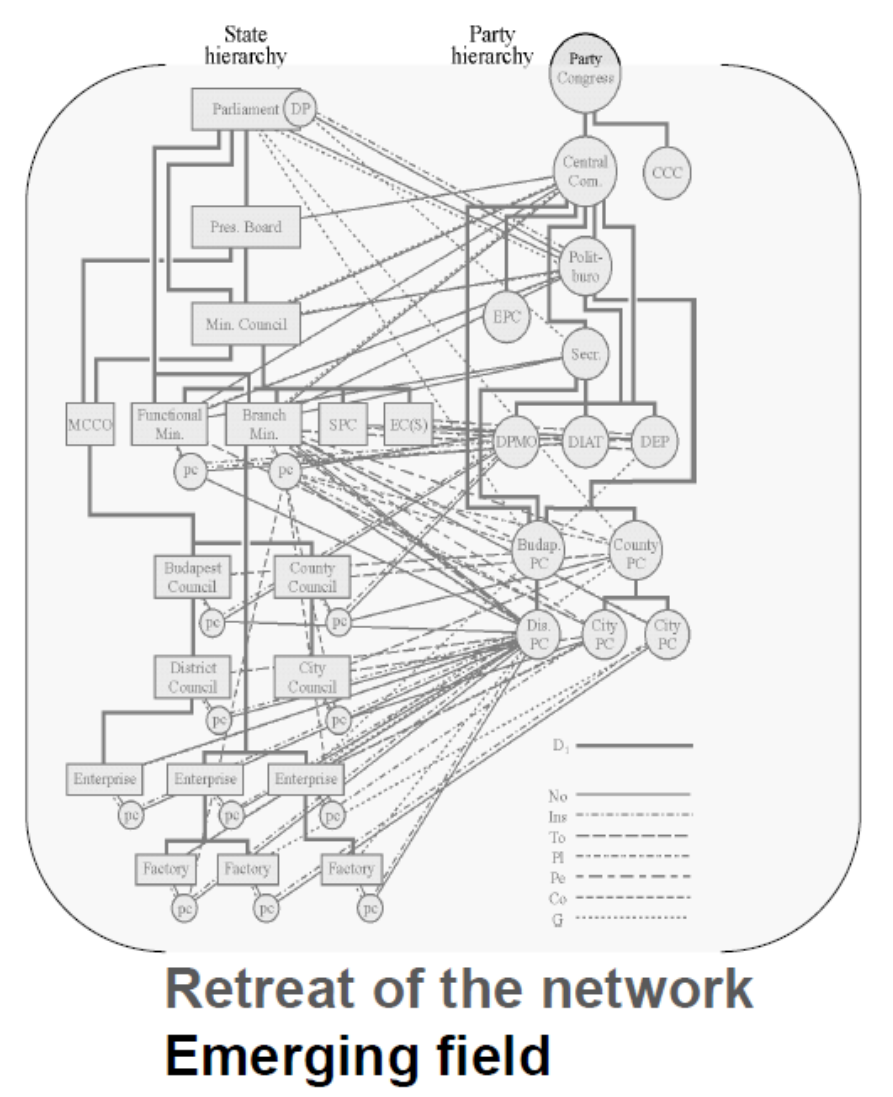

The more sudden the collapse, the higher is the cumulated uncertainty, the harder it is to adapt to the changing environment, the longer and deeper the economic crisis, the slower the formation of market-friendly institutions, the greater the stratification of the society and the formation of dissident groups and coalitions among them be they economic, political or civil initiatives. In such cases the opportunity grows for authoritarian domination of economic and political transformation or for its stagnation and the state to be captured by the political leadership, cliques and fragments of former networks. 
Figure 7/a reflects the characteristic sequence, speed and conditions of transformation in the Self-disintegrating pattern. In this pattern political transformation comes first and changes are gradual. Since economic transformation comes second, economic transformation develops under a democratic political regime while political transformation develops during a macroeconomic crisis.

Figure 7/a Nature of system transformation in the Self-disintegrating pattern

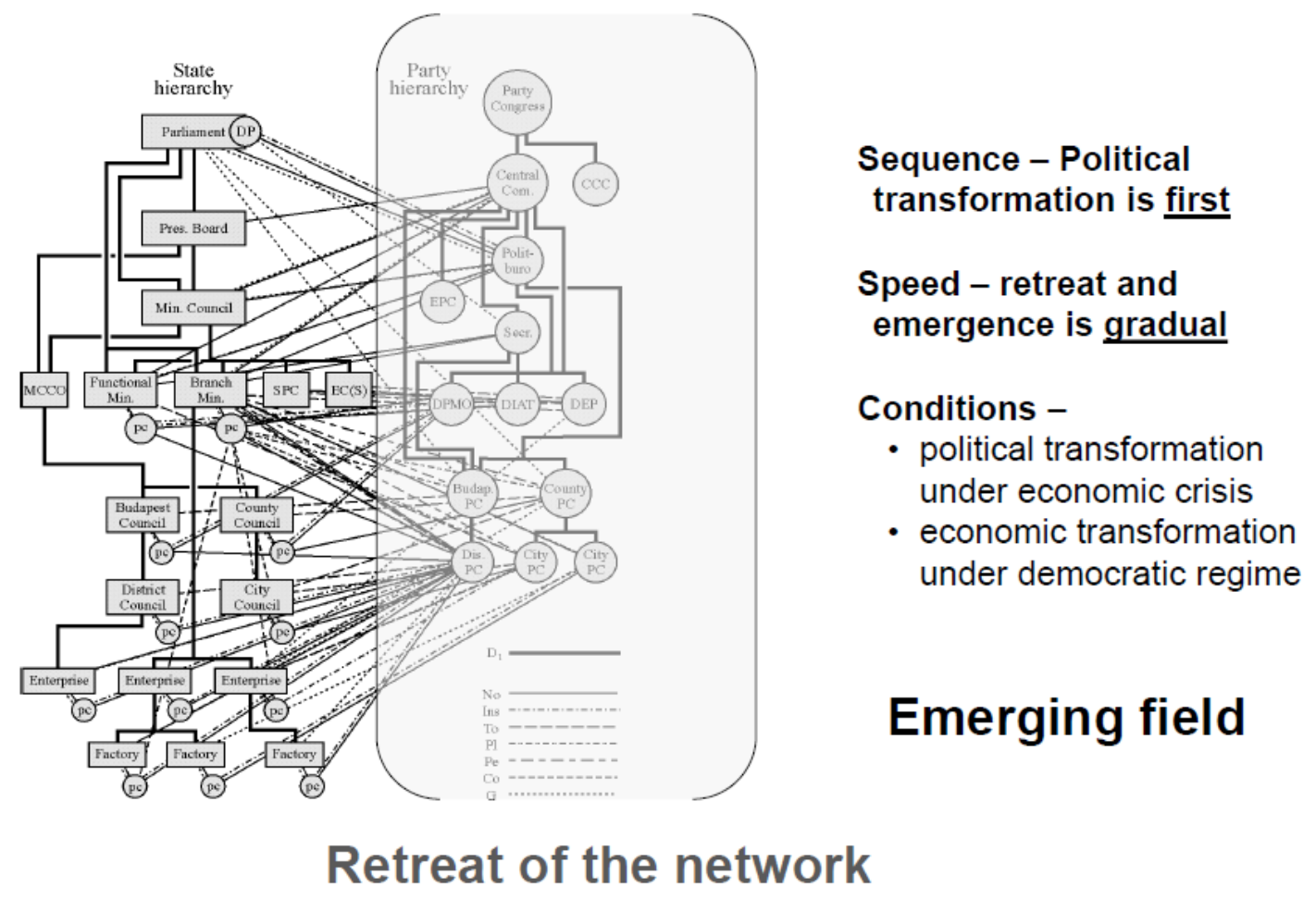

Figure $7 / \mathrm{b}$ involves the gradual metamorphosis of the party reversing from a social system into a political entity. Factors are inherent to this dynamics of retreat of the network: first the escalation of the decentralization process takes place within the network directly sensitive to economic crisis, generally to get rid of the responsibilities, while the party is losing legitimacy owing to repeatedly failed economic reforms to curb the recesssion spiral. Decentralization 
takes place among the discretions over economic units within the state and party hierarchies. ${ }^{13}$ The network was emptied as cohesion loosened and interactivity declined as a result of lower expectations to attract resources within the net, competitive staff of the party and state fled the apparatus to find new jobs outside the network and new party membership in the expanding new political field. As distributive capacity through the net waned, vertical and interlinking lines were withdrawn as distributive functions and positions in the party were abolished. Without functions, these moves were followed by the dissolution of the party apparatus which once held the interlinking lines while in the party, power struggles cristallized and horizontal platforms were allowed. The dissolution of the apparatus was followed by the abolition of the Communist Party and members were released. Without power and respective instruments, the Party split into two political parties, a reformist and a conservative wing, completing the reversed metamorphosis.

\section{Figure 7/b The components of the retreating network}

\footnotetext{
${ }^{13}$ For example, such was the new system of enterprise management where candidates, after being listed by local party apparatus were elected by workers and staff of the enterprise instead of being appointed by the supervising ministry.
} 


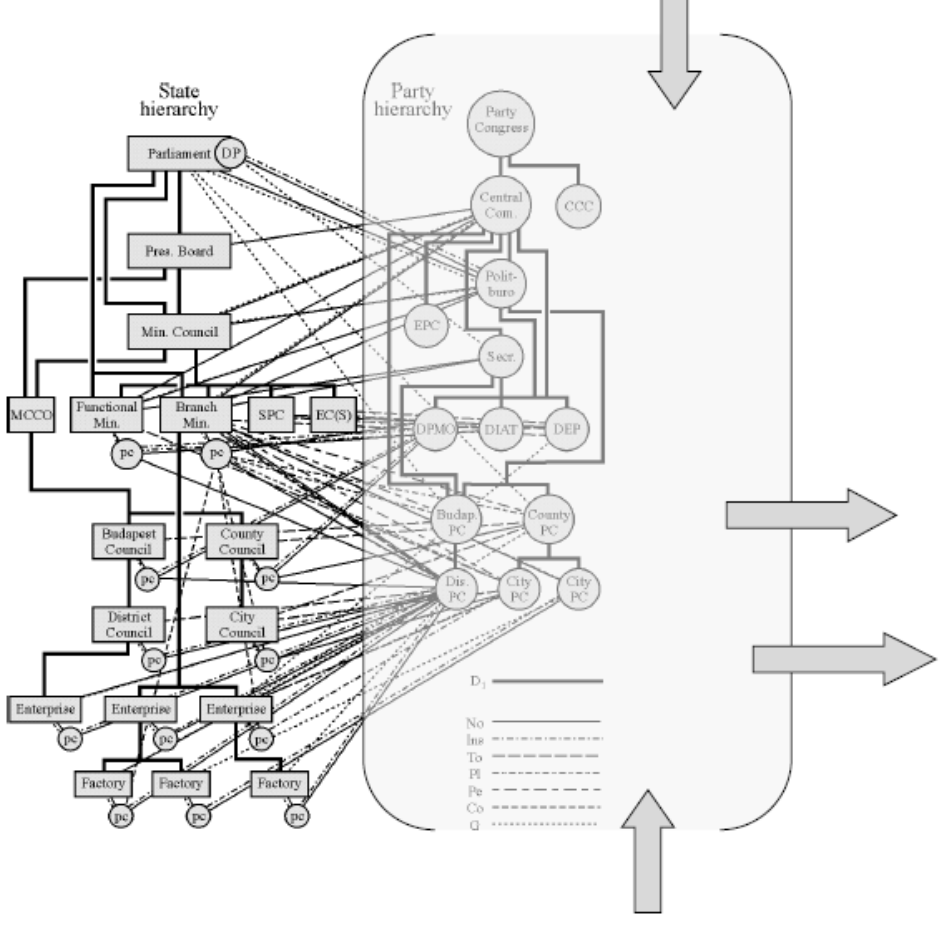
Decentralizing interlinking lines

Emptying of the network

Withdrawal of vertical and interlinking lines of the party

Cut-off of dependency lines

Streamlining feedbacks and interlinking lines

Allowing horizontal platforms within the network

Abolishing the Party's hegemony

Abolishing the Party apparatus

Abolishing the Party

Figure 7/c deals with the factors of an evolving and expanding new political sub-sphere both external to the retreating network and within the space that emerged among the broken lines of the network. This process was in tight interaction with the retreating network from the monopolized political sub-sphere as a result of forced but inefficient adaptation to the internal and external economic pressures. First horizontal groups such as NGOs were allowed to emerge outside the network, later also pressure groups emerged that were subsequently reorganized into historic or new political parties. These parties were founded or joined by former party members or staff who had left the network. Extra-parliamentary forces and a reformist wing in roundtable talks oversaw the introduction of crucial democratic laws that required a two-thirds majority to enact. The old parliament passed these bills under external pressure before its dissolution. Thus a multiparty-system was officially introduced, free elections were held, a new parliament was formed and the democratic political system institutionalized (Csanádi 1997). 
Figure 7/c The components of the emerging field

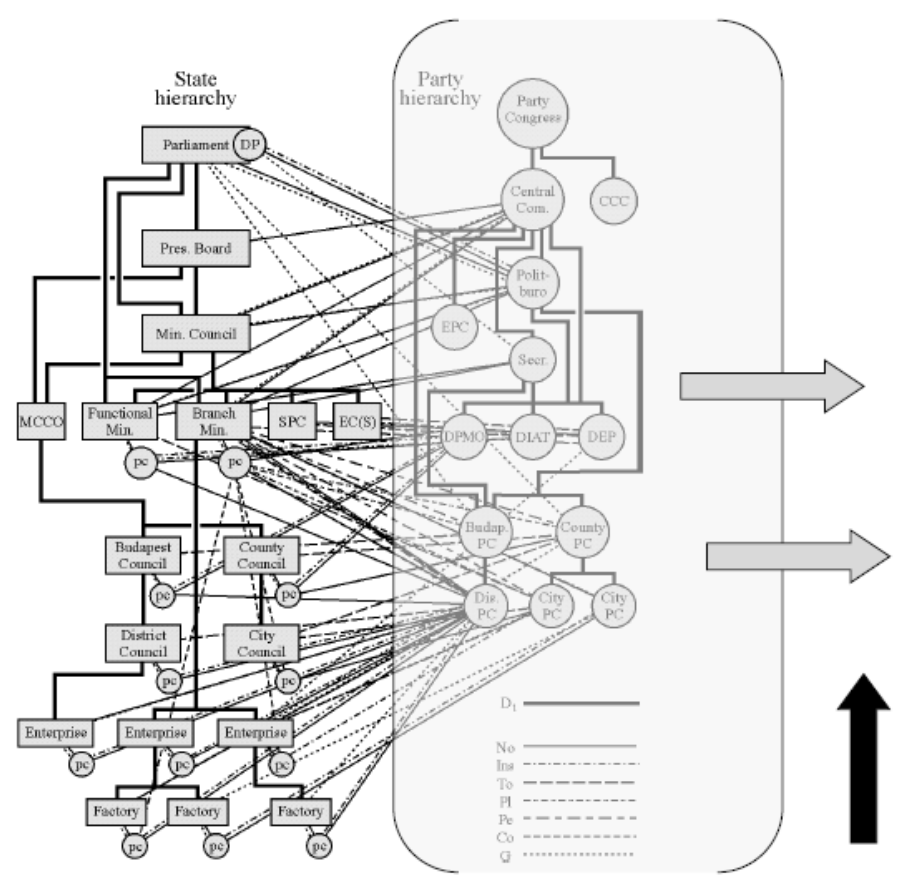

Allowing horizontal groups to emerge outside the net

- formation of NGOs

- formation of interest groups

- formation of parties

Former party members join new organizations Institutionalization of the multiparty system Institutionalizing democratic political regime

Figure 8/a reflects the metamorphosis of the party-state system while retreating first from the economic sub-field of both agriculture and industry. In this pattern, the speed of economic transformation is gradual, the process of economic transformation occurs under authoritarian rule, while owing to the expanding competitive field macroeconomic growth takes place forging the external sources for the self-reproduction of the remaining network. Both macroeconomic growth and self-reproductions of the network provide legitimacy for the party.

Figure 8/a Nature of system transformation in the Self-withdrawing pattern 


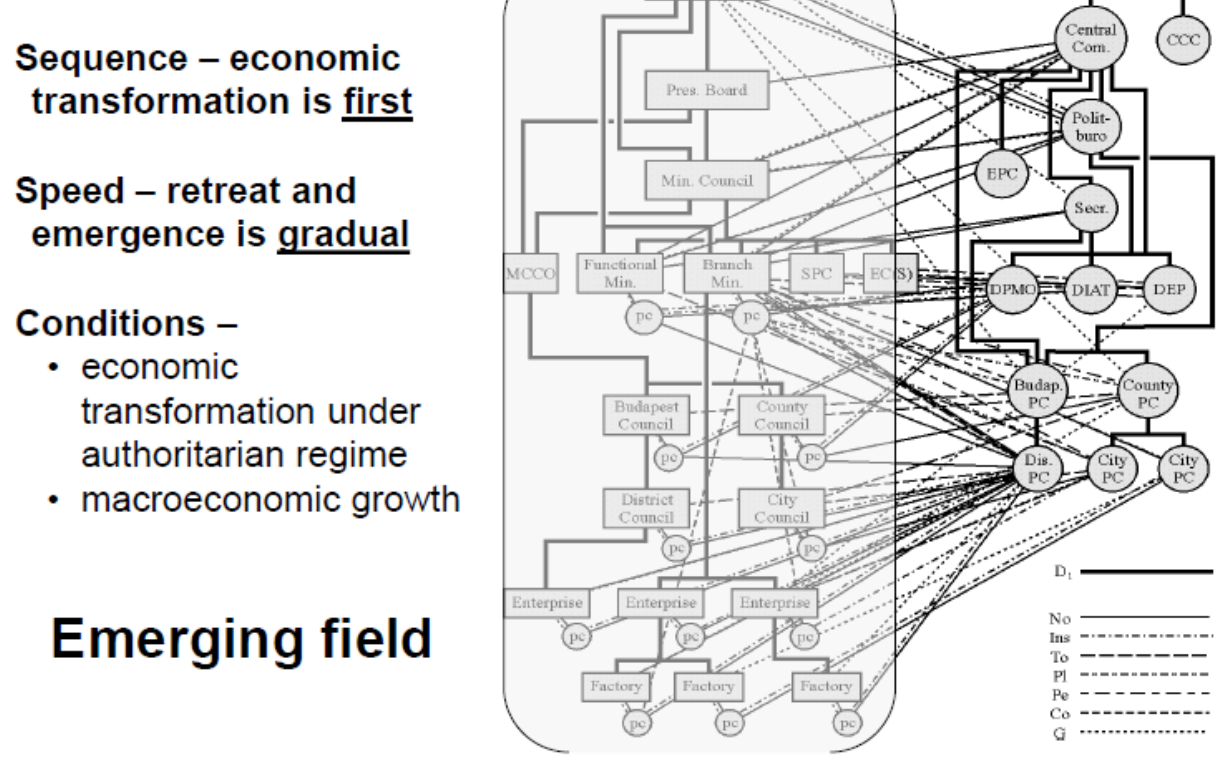

\section{Retreat of the network}

Owing to the interwined and self-similar structural and operational characteristics of the system as a network, components and processes of retreat and emergence in the economic sub-sphere resemble those in the political sub-sphere (Figure 8/b). Retreat of the network may be traced in different sub-sectors of the economy. The network retreated first from grass-roots agriculture by cutting dependency lines with the dissolution of production cooperatives, the creation of an individual responsibility system (a household responsibility system) and also the withdrawal of the network by gradually narrowing the fixed price of state procurement and that of the number of products falling under it and implicitly allowing the expansion of migration despite the conservation of the local hukou system. Also, the retreat of the network was gradually taking place in the the industry. Here too, the process began with decentralization of decisions within the network to bring decisions to the level of production in marketing, investment, expansion plans, and staff (enterprise and manager responsibility system) and provided profit retention opportunities. Later competitive capital, manpower and organizations empty (flee) the network to join the expanding market sphere. At the same time, 
alternative capital, actors and interests enter the network (joint ventures, shareholdings,

Peoples' Parliament, inter-ministerial committees etc.) formally and informally weakening the influence of the party on the economy through the network while contributing to its selfreproduction. In exchange, the party's informal and formal influence on the private sphere expands. Former distributive functions were withdrawn from the lower levels allowing enterprises greater freedom in deciding about investments up to a certain volume. The network has been increasingly cut through privatization, close-downs and bankruptcy of stateowned enterprises, leaving the direct interlinking and hierarchical lines in limbo.

Figure 8/b the components of the retreating network

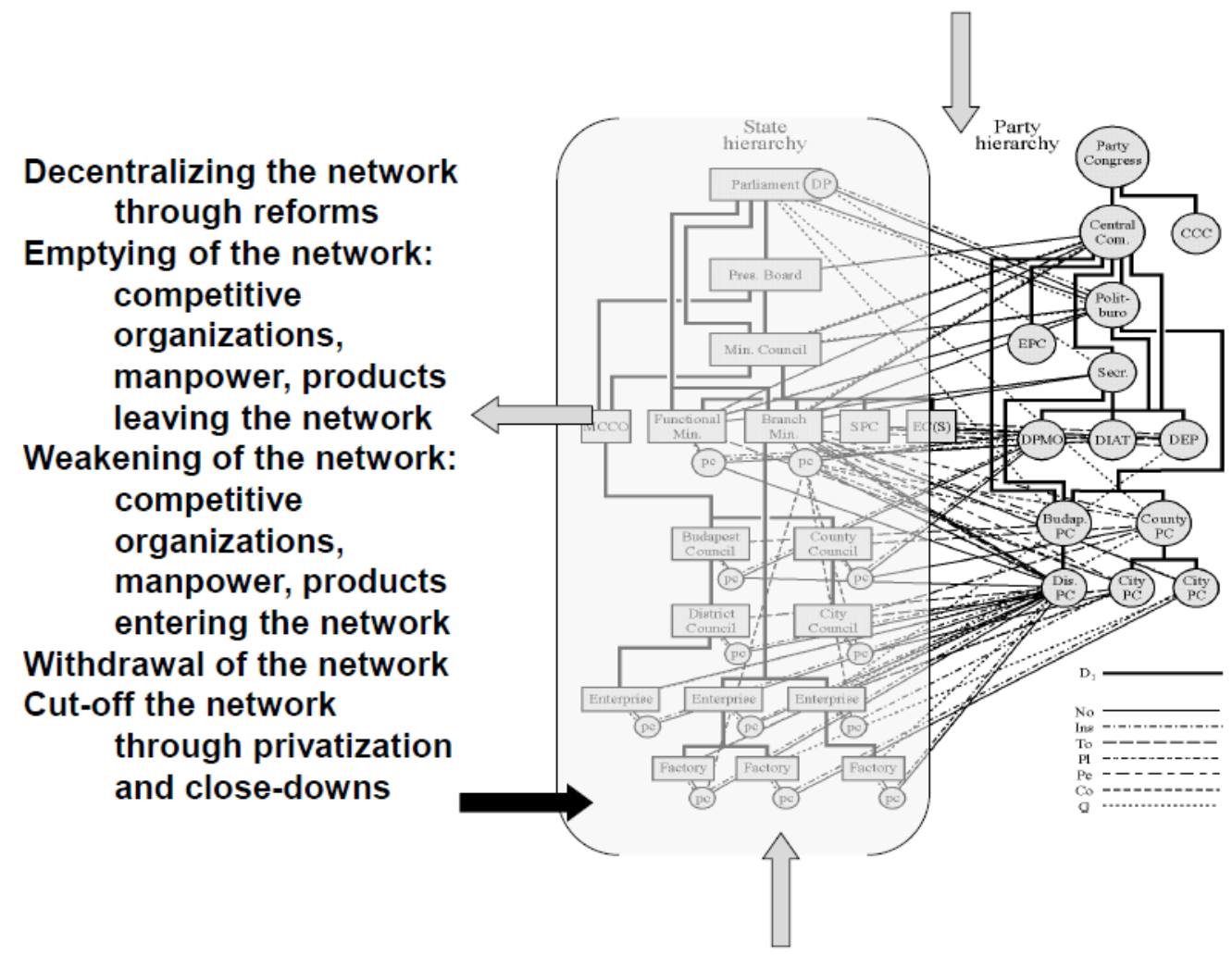

Meanwhile (Figure 8/c) dual-track pricing regulations were created in both agriculture and industry that allowed producers to sell their over-the plan products on market prices. These decisions contributed to market expansion in agricultural and industrial products and increased savings. Besides dual track system, further expansion of the market was allowed by 
"opening up" attracting resources from the global economy in the form of FDI. New private enterprises, both domestic and foreign, were allowed to be set up, the number of special economic zones were increased and investment-friendly laws were implemented that contributed to the further expansion of the market. All these factors complemented the number of privatized enteprises, transferred capital, organization and manpower from the network sphere, including the fast growing number of migrants absorbed by the expanding competitive sphere.

Figure 8/c The components of the emerging field
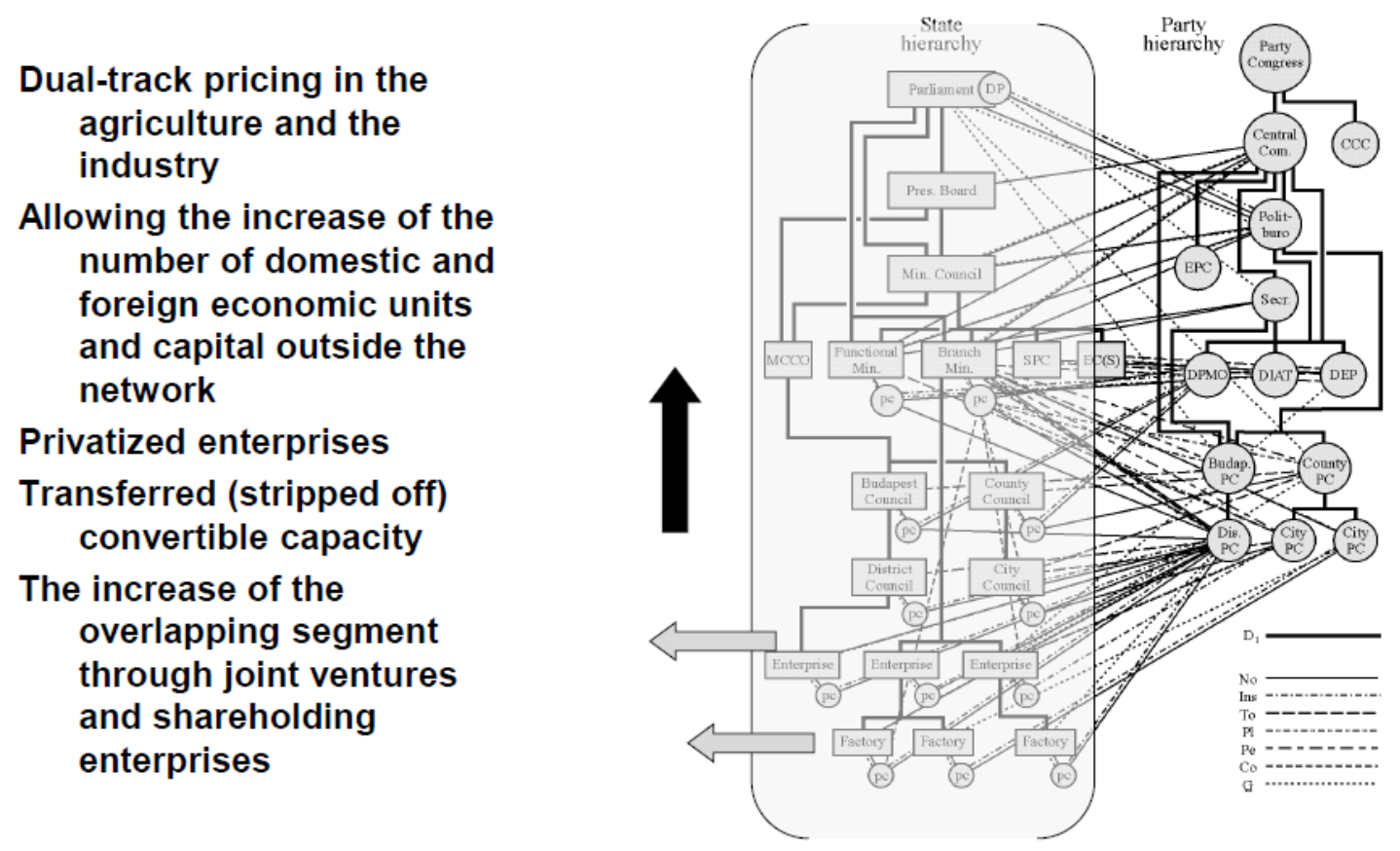

\section{Conclusion}

We have demonstrated that with the implementation of the IPS model the main characteristics of the structure, operation and transformation of Communist states and their different aggregation levels may be analyzed on common grounds. Comparison is possible no matter if they had already vanished or still prevail, they were in scattered or clustered geopolitical locations, have or had different sizes, history, culture, level of economic development and 
economic structure, a diverse starting period of system formation, distinct stages, sequences, speed and conditions of transformation, or experienced historically different external influence in different periods in one or in several party-states etc. This is because in the IPS model party-state systems are described as politically monopolized networks characterized by the self-similarity, fractal property, of the composing elements, connecting and operating principles in time, space and aggregation levels.

Based on this network we can complexly and systematically handle the otherwise dichotomist dynamic concepts like center-periphery, principal-agent, state-society, party-state, economypolitics, central authoritarianism-local federalism and central planning and local governance as different aspects of the same power relations that form the network. Essential to the basis of comparison is that these networks evolve, change and transform through the interaction between party, state, and economic decision-makers, based on politically rational economic behavior inspired by the characteristics of the network and external impacts. The same selfsimilar characteristics of the network motivate selective distribution of resources that create politically rational fixed paths according to scale, state ownership and extent of integration into the decision-making process. As a result, selectively, and not uniformly, soft reproduction constraints motivate the unbounded drive for growth and integration of economic actors into the network that will lead to repeated investment overheating in such systems.

At the same time, the IPS model serves as an analytical framework to the sheer variety of the structure, operation and transformation of party-states provided by the combination of the varieties of power distribution and its consequences both in different time, geographical space and different levels of aggregation in the network that will determine country specifics. Variations in power distribution emerge through the level of centralization of power instruments in the party hierarchy stretching out and overlapping party and non-party fields, 
the level of centralization of extraction and distribution of resources in the state hierarchy and the level and depth of integration of actors into the party and state hierarchy. Individual characteristics like size, history, culture, level of economic development and economic structure, geopolitical location, historical starting period of system formation etc. will influence which combination of the network will become institutionalized.

Patterns of power distribution invoke pattern-conforming instruments of resource extraction and allocation within the network for its self-reproduction. Variations define the frequency of meeting hard reproduction constraints of the network that requires repeated deployment of pattern-conforming measures. In this respect, the interactivity in the model reflects the strong interrelation among self-reproduction and dynamics of retreat and emergence by linking the frequency of hardening constraints of self-reproduction and according deployment of patternconforming measures to transformation and external context. The model takes external economic constraints (exerted by the field outside the network, either domestically or abroad), and internal structural constraints (depending on internal power distribution) simultaneously into consideration in their mutual dynamic impact on the system's self-reproduction. All these impacts may occur in different stages of the reproduction dynamics: both during the period of self-reproduction and during transformation with different consequences. These same external and internal constraints combined with different time-span explain the differences in the reactions to adaptation pressures of the same patterns and that of different patterns. In case of simultaneous and persistent external and internal pressures the frequency of meeting hard resource constraints during self-reproduction increases, and the implementation of these measures escalates and may lead to system transformation.

The model is able to distinguish decentralization, reforms, marketization and system transformation, frequently taken as synonyms in comparative literature, by integrating them and their complex functions into power relations. Decentralization of decisions means a 
certain redistribution of power within the network no matter what the pattern is. Reforms, be they from below or above, or even neglected in the model are pattern-conforming instruments of self-reproduction of the party-state system, either within or outside the network; marketization is one usual variant of the emergent field outside the network during the process of the transformation (retreat and emergence) of the economic sub-field; while transformation is a process of pattern-conforming system change either with or without reforms, through sudden collapse, or gradual retreat and emergence, in different sequence (economic or political transformation first) and different political and economic conditions and with different possible outcomes.

Interpreted in this comparative systemic context, China's self-withdrawing structural pattern provides answers to its specific dynamics: the Chinese style reforms "from below", economic transformation first, the gradual market expansion and macroeconomic growth under authoritarian rule, the legitimacy of the communist party, its repeated preferences in selective resource distribution on central and local levels to large and state-owned and well connected enterprises, the persistent drive for growth and resource hoarding behavior of economic actors both enterprise managers and local governments, the repeated overheating, the decentralized institutional functions paired with growing local indebtedness, persistent growth of nonperforming loans and shadow banking and significant corruption in a politically monopolized transforming system.

Acknowledgements: I owe my professional development and theoretical and empirical findings to the personal and professional support of András Lörincz, István Hagelmayer, Zsolt Papp, László Antal, Mihály Laki, Károly Fazekas, János Köllő, K. Attila Soós, Ferenc Gyuris, Liu Hong, Li Shi, Lai Hairong, Mao Yushi, Wu Jinglian, Yu Yongding, Fu Xiaolan, Liu Xiaoxuan and Nie Zihan and to my research team composed of the Masters and PhD students at Beijing Normal University. I am also grateful to the anonymous reviewer for the thorough 
comments that radically improved my work and to Richard Lingwood, who has edited my paper carefully.

\section{References:}

Aslund, Anders. (1993) Comment on "Gradual versus Rapid Liberalization in Socialist Economies by McKinnon, Proceedings of the World Bank Annual Conference on Development Economics.

Bohle, Dorothy. (2010). Countries in distress: transformation, transnationalization, and crisis in Hungary and Latvia” emecon, 1 www.emecon.eu/Bohle.

Bohle, Dorothy and Béla Greskovits. (2012). Capitalist Diversity on Europe's Periphery (Cornell Studies in Political Economy) Cornell University Press, Cornell Studies in Political Economy.

Bunce, Valerie. (1985). 'The Evolution of the Eastern Bloc from a Soviet Asset to a Soviet Liability.' International Organization, 39 (Winter, 1984/1985): 1-46.

Bunce, Valerie. (1995), “Should Transitologists Be Grounded?" Slavic Review 54, No. 1 (Spring): 111-127.

Bunce, Valerie. (1999) Subversive Institutions: The Design and the Destruction of socialism and the State Cambridge Univesrity Press, Cambridge UK.

Bunce, Valerie and Maria Csanádi. (1993) "Uncertainty in the Transition: Postcommunism in Hungary" East European Politics and Societies, 7 (Spring): 32-50.

Carothers, Thomas. (2002): 'The End of Transition Paradigm' Journal of Democracy 13:1: 521.

Cao, Yuanzheng, Yingyi Qian and Barry Weingast. (1999): “From Federalism, Chinese Style to Privatization, Chinese Style" Economics of Transformation 7 No. 1: 103-131. 
Chen, K., G. Jefferson and Inderit Singh. (1992): "Lessons from China's Economic Reform" Journal of Comparative Economics Vol. 16, No. 2: 201-225.

Csanádi, Maria. (1997). Party-states and their Legacies in Post-communist Transformation. Edward EIgar, Cheltenham, UK.

Csanádi, Maria. (2005). 'Reforms and Transformation Paths in Comparative Perspective: Challenging Comparative Views on East European and Chinese Reforms' Acta Oeconomica. Vol. 55, No. 2, pp. 171-198.

Csanádi, Mária. (2006). Self-Consuming Evolutions: A Model on the Structure, Selfreproduction, Self-destruction and Transformation of Party-states, Tested on the Romanian, Hungarian and Chinese Cases. Hungarian Academic Press, Budapest. Csanádi, Mária. (2011). "Varieties of System Transformations and Their Structural Background Based on the IPS Model”, Discussion Papers, MT-DP -2011/5, http://econ.core.hu/file/download/mtdp/MTDP1105.pdf.

Csanádi, Maria. (2013) State Intervention, Local Indebtedness, Investment Overheating and Their Systemic Background During Global Crisis in China http://econ.core.hu/file/download/mtdp/MTDP1340.pdf .

Csanádi, Maria and Liu Xiaoxuan. (2012) Crisis and selective adaptation in a Chinese prefecture between 2008 and 2010: a survey among industrial enterprises. MT-DP 2012/35 http://econ.core.hu/file/download/mtdp/MTDP1235.pdf .

Denglian, Jin. and Kingsley E. Haynes. (1997) "Economic Transition at the Edge of Order and Chaos: China's Dualist and Leading Sectoral Approach" Journal of Economic Issues XXXI. No. 1, (March): 79-100.

Dewatripoint and Eric Maskin. (1995): “Credit Efficiency in Centralized and Decentralized Economies" Review of Economic Studies 62, No. 4, (October): 541-55. 
Dollar, David. (1994) "Macroeconomic Management and the Transition to the Market in Vietnam" Journal of Comparative Economics 18 No. 3: 357-390.

Dorenspleet, Renske. (2004) The structural context of recent transitions to democracy European Journal of Political Research 43: 309-335.

Gelb, Allan, Garry Jefferson and Inderjit Singh. (1993) "Can Communist Economies Transform Gradually? The Experience of China" in Olivier Blanchard and Stanley Fisher, eds., NBER Macroeconmics Annual (Cambridge: MIT Press), 87-133.

Gomulka, Stanislaw. (1994):“Economic and Political Constraints during Transition' Europe”. Asia Studies 46 No. 1: 89-106.

Goodman, David S. G. and Gerald Segal eds. (1994).: China Deconstructs (London, NY.: Routledge): 152-58.

Granick, David. (1990): Chinese State Enterprises: A Regional Property Rights Analysis (Chicago: Chicago University Press).

Hale, David. January/February 2001 issue of The International Economy (www.theinternationaleconomy.com, 3.

Hellman, Joel.(1998): "Winners Take All: the Politics of Partial Reform in Post-communist Transformations" World Politics 50 (January): 203-3.

Huang, Yasheng. (1990): "Web of Interest and Patterns of Behavior of Chinese Local Economic Bureaucracies and Enterprises during Reforms" China Quarterly 123 (September): 431458.Kornai, János. (1993) Bureaucratic and Market Coordination: 306-319

Kornai, János. (1994): “Transformational Recession: The Main Causes.”Journal of Comparative Economics 19, Academic Press 39-63. 
Kumon, Shumpei. (1992) Japan as a Network Society: 109-141 in: Shumpei Kumon and Henry Rosovsky (eds) The Political Economy of Japan, Volume 3 Cultural and Social Dynamics.

Lai, Hairong. (2004). "Semi-Competitive Elections at Township Level in Sichuan Province", China Perspectives [Online], 51 | january-february 2004, Online since 20 April 2007, connection on 02 July 2016. URL : http://chinaperspectives.revues.org/787.

Lin, Li-Wen and Kurtis J. Milhaupt. (2011). We are the (National) Champions: Understanding the Mechanisms of State Capitalism in China Columbia Law and Economics Working Paper No. 409. http://papers.ssrn.com/sol3/papers.cfm?abstract id=1952623.

Mandelbrot, B. B. (1983) "The Fractal Geometry of Nature" San Francisco: Freeman and Co. Naughton, Barry. (1996): Growing Out of the Plan Chinese Economic Reform, 1978-1993, (Cambridge: Cambridge University Press).

Nolan, Peter. (1996): 'China's Post-Mao Political Economy: A Puzzle' in Political and Economic Liberalization: Dynamics and Linkages in Comparative Perspective. Nonneman Gerd ed. (Colorado: Lynne Rienner Publishers), 287-307.

Nolan, Peter. (2014): Globalisation and Industrial Policy: the Case of China The World Economy Volume 37, Issue 6: 747-764, June 2014.

Pearson, Margaret M. (1997): China's New Business Elite. The Political Consequences of Economic Reforms (Berkeley, L. A. London: University of California Press).

Qian Yingy and Chengang Xu. (1993): "Why China's Economic Reforms Differ: the M-form Hierarchy and Entry/Expansion of the Non-state Sector" Economics of Transition_1, No. 2: 135-170. 
Qian, Yingyi and G. Roland. (1998): "Federalism and Soft Budget Constraint" The American Economic Review 88, No. 5 (1998): 1143-62.

Sachs, Jeffrey. (1994): "Russia's Struggle with Stabilization: Conceptual Issues and Evidence" In M. Bruno and B. Pleskovic eds Proceedings of the World Bank Annual Conference on Development Economics (Washington, DC: World Bank).

Sachs, Jeffrey and Wing Thye Woo. (1997): "Understanding China's Economic Performance" NBER Working Paper, (October) N. 5935.

Schelkle Waltraud. (2000) "Paradigms of Social Change: Modernization, Development, Transformation, Evolution” (Campus Verlag-Frankfurt/New York St. Martin's Press-New York).

Shirk, Susan. (1993): Political Logic of Economic Reform sin China (Berkeley, University of California Press).

Solinger, Dorothy J. (1993): China's Transformation from Socialism. Statist Legacies and Market Reforms 1980-1990. (Studies of the East Asian Institute, Columbia University). (New York - London: M.E. Sharpe).

Sun, Laixang. (1997): Emergence of Unorthodox Ownership and Governance Structures in East Asia. An Alternative Transition Path. Research for Action 38 UNU World Institute for Development Economics Research (UNU/WIDER).

Szalontai, Balázs and Changyong Choi. (2012). "The Prospects of Economic Reform in North Korea: Comparisons with China, Vietnam and Yugoslavia” Europe-Asia Studies Vol. 64, No. 2, March 2012, 227-246.

Walder, Andrew G. (1995): "China's Transitional Economy: Interpreting its Significance” The China Quarterly 143: 963-79. 
Weingast, Barry. (1995): “The Economic Role of Political Institutions: Market-Preserving Federalism and Economic Development” Journal of Law, Economics, \& Organization 11: 131.

Wildasin, D. E. (1997): "Externalities and Bailouts: Hard and Soft Budget constraints in Intergovernmental Fiscal Relations" Mimeo, Vanderbilt University.

Wong, Christine. (1985): "Material Allocation and Decentralization: Impact of the Local Sector on Industrial Reform" in Elisabeth J. Perry and Christine Wong eds. The Political Economy of Reform in Post-Mao China (Cambridge, MA: Harvard University Press), 253-278.

Woo, Wing Thye. (1998): "Why China Grew" in Emerging from Communism: Lessons from Russia, China, and Eastern Europe ed. Boone, Peter, Stanislaw Gomulka, and Richard Layard (MA, London: MIT Press Cambridge), 153-182.World Bank. (1996): World Development Report, From Plan to Market, (Oxford, Oxford University Press).

Yu, Yongding. (2010) The Impact of the Global Financial Crisis on the Chinese Economy and China’s Policy Responses” Financial Crisis and Asian Developing Countries. Third World Network, Global Economy Series No. 25.

Yu, Yongding. (2014) Taming the China Bears" Project Syndicate http://www.projectsyndicate.org/commentary/yu-yongding-argues-that-predictions-of-a-hard-economiclanding-are-largely-unwarranted . 